\title{
Sexual dimorphism of craniological characters in the Altai weasel Mustela altaica (Carnivora, Mustelidae)
}

\author{
Andrey Yu. Puzachenko, Ryuichi Masuda \& Alexei V. Abramov*
}

\begin{abstract}
A morphometric variation in 23 characters of 77 skulls of the Altai weasel Mustela altaica from the delta of Ili River in Kazakhstan has been analysed. Multivariate analyses (nonmetric multidimensional scaling and multivariate allometry) were used to estimate a sexual size dimorphism (SSD) in cranial characters. A high degree of the sexual dimorphism was found in the Altai weasel population. All morphometric characters in the males were larger than those in the females. An average sexual size dimorphism (ASSD) of $M$. altaica lies within the genus Mustela range. In this species, the SSD is a result of differences in the scale and allometry of cranial characters between sexes, reflecting the differences in male/female allometric ontogenetic patterns. The results are discussed in relation to the existing hypotheses on sexual dimorphism in the mustelids: food competition, sexual selection, and differences in reproductive strategies.

How to cite this article: Puzachenko A.Yu., Masuda R., Abramov A.V. 2019. Sexual dimorphism of craniological characters in the Altai weasel Mustela altaica (Carnivora, Mustelidae) //Russian J. Theriol. Vol.18. No.1. P.12-19. doi: 10.15298/rusjtheriol.18.1.02.
\end{abstract}

KEY WORDS: Mustela altaica, multivariate allometry, mustelids, sexual size dimorphism, skull variation, Kazakhstan.

Andrey Yu. Puzachenko [andreypuzak@gmail.com], Institute of Geography, Russian Academy of Sciences, Staromonetnyi per. 22, Moscow 109017, Russia; Ryuichi Masuda [masudary@sci.hokudai.ac.jp], Department of Biological Sciences, Faculty of Science, Hokkaido University, Sapporo 060-0810, Japan; Alexei V. Abramov [alexei.abramov@, zin.ru], Zoological Institute, Russian Academy of Sciences, Universitetskaya nab. 1, Saint Petersburg 199034, Russia.

\section{Половой диморфизм краниологических признаков у солонгоя Mustela altaica (Carnivora, Mustelidae)}

\author{
А.Ю. Пузаченко, Р. Масуда, А.В. Абрамов*
}

\begin{abstract}
РЕЗЮМЕ. Проанализирована морфометрическая изменчивость 23 признаков 77 черепов солонгоя Mustela altaica из дельты реки Или в Казахстане. Многомерный анализ (неметрическое многомерное шкалирование и многомерная аллометрия) был использован для оценки размерного полового диморфизма (SSD) краниологических признаков. Обнаружена высокая степень полового диморфизма в исследованной популяции солонгоя. По всем морфометрическим признакам самцы были крупнее самок. Средний уровень размерного полового диморфизма (ASSD) M. altaica находится в пределах изменчивости рода Mustela. У солонгоя SSD является результатом различий в размерах и аллометрии черепных признаков между полами, отражая различия в аллометрических онтогенетических паттернах у самцов и самок. Результаты обсуждаются в связи с существующими гипотезами о половом диморфизме у куньих: пищевая конкуренция, половой отбор и различия в репродуктивных стратегиях.
\end{abstract}

КЛЮЧЕВЫЕ СЛОВА: Mustela altaica, многомерная аллометрия, куньи, размерный половой диморфизм, изменчивость черепа, Казахстан.

\section{Introduction}

Sexual size dimorphism (SSD) is a common phenomenon among most mammals. Weasels of the genus Mustela (Carnivora, Mustelidae) are well-known for the remarkable body size differences between sexes, with the males being much bigger and stronger than the females.

Detailed studies on the SSD in craniometric characters have been carried out on several Mustela species: the least weasel M. nivalis (Reichstein, 1957; Schmidt,

* Corresponding author.
1992; Reig, 1997), the long-tailed weasel M. frenata (Ralls \& Harvey, 1985), the Siberian weasel $M$. sibirica (Abramov \& Puzachenko, 2009), the European mink M. lutreola (Abramov \& Tumanov, 2003), the stoat M. erminea (Reichstein, 1957; Ralls \& Harvey, 1985), and polecats $M$. putorius and M. eversmanii (De Marinis, 1995; Smetanová, 2011; Abramov et al., 2016). Of all the widespread Palaearcic weasels, the Altai weasel Mustela altaica Pallas, 1811 is the only species that has not been studied yet. The Altai weasel is distributed in central and east Asia, with a range covering most of China, Pakistan, the Himalaya in India, Nepal and Bhutan, 
eastern Kazakhstan, Kyrgyzstan, Tajikistan, Mongolia, some parts of south-eastern Siberia and the Russian Far East (Abramov, 2016). Intrapopulation and geographic morphological variations, particularly in cranial characters of the Altai weasel, remain underexplored and their sexual dimorphism has not been clarified yet.

The aim of this work is to study a sexual dimorphism of cranial characters in the Altai weasel. This species is rare in most parts of its distribution range, and hence specimens are scarce in museum collections worldwide. The valley of the River Ili near Lake Balkhash in eastern Kazakhstan is the only region where the Altai weasel was known to be abundant (Heptner et al., 1967). During 1930-70s, the species was actively collected for fur in that area, with more than 23,000 animals being trapped just in 1933 (Sludsky et al., 1982). Some of the specimens from the delta of Ili River were deposited in zoological collections. Since we have a large homogeneous sample of the Altai weasel collected from one site, we are able to assess the sexual dimorphism of its craniological characters without the influence of geographic variability.

\section{Material and methods}

A total of 77 (22 females, 55 males) intact skulls of adult Altai weasels from the delta of Ili River in Kazakhstan (ca. $45.28^{\circ} \mathrm{N}, 75.19^{\circ} \mathrm{E}$ ) were analyzed. The specimens are kept in the collections of the Zoological Institute, Russian Academy of Sciences (Saint Petersburg, Russia), the Zoological Museum, Moscow State University (ZMMU, Moscow, Russia), and the Kazakh Anti-plague Research Institute (Almaty, Kazakhstan).

Twenty three measurements were taken from each skull using digital calipers to the nearest $0.1 \mathrm{~mm}$ : condylobasal length $(\mathrm{CbL})$, neurocranium length $(\mathrm{NcL})$, viscerocranium length $(\mathrm{VcL})$, minimal palatal width $(\mathrm{MpW})$, palatal length (PL), maxillary tooth-row length (MxtL), upper carnassial tooth Pm4 length (PM4L), length of the auditory bulla $(\mathrm{AbL})$, greatest length between oral border of the auditory bulla and aboral border of the occipital condyles (BcL), zygomatic width (ZyW), mastiod width of skull (MW), postorbital width (PoW), interorbital width (IW), width of rostrum (RW), greatest palatal width $(\mathrm{GpW})$, width of the auditory bulla (AbW), width of upper molar M1 (M1W), cranial height $(\mathrm{CH})$, total length of the mandible (ML), length between the angular process and infradentale (AL), mandibular tooth-row length (MatL), length of lower carnassial tooth M1 (M1L), height of mandible in the vertical ramus $(\mathrm{MaH})$. See Abramov \& Puzachenko (2009) for the scheme of measurements. The measured skull characters are listed in Table 1 . The age classes were defined by skull characters, including the development of crests, suture obliteration, tooth wear, etc.

As a measure of the sexual dimorphism by single measurement, we chose both absolute mean difference between sexes $(\Delta \mathrm{S}, \mathrm{mm})$ and the ratio of $\Delta \mathrm{S}$ to male size $\left(\Delta(\mathrm{M}-\mathrm{F})=100 \times(\Delta \mathrm{S}) / \mathrm{M}_{\mathrm{M}}\right)$. SSD index was calculated as: $\mathrm{SSD}=100 \times\left(\Delta \mathrm{S} / \mathrm{M}_{m}+\mathrm{M}_{\mathrm{F}}\right)$. An average $\mathrm{SSD}$ was calculated as $\mathrm{ASSD}=\frac{1}{m} \sum^{m \mathrm{MSD}}$, where $m$ was number of measurements.
In the model of morphological space or morphospace (Puzachenko, 2001, 2016; Kupriyanova et al., 2003; Abramov et al., 2009, 2018; Abramov \& Puzachenko, 2009, 2012; Baryshnikov \& Puzachenko, 2011, 2012, 2017; Puzachenko et al., 2017), the morphological system was defined as a sample set of skulls (elements), which were defined by a set of measurements. Two morphospaces were constructed using the Nonmetric Multidimensional Scaling (NMDS) technique (Davison \& Jones, 1983) based on the matrixes of Euclidean distances and Kendall's tau-b (corrected for ties) associations (Kendall, 1975) amongst all pairs of skulls. The Euclidean metric produces the common Euclidian space with the orthogonal coordinate system. The metric based on Kendall's coefficients causes a curvilinear surface, which, as a result of NMDS, can be projected onto the Euclidian space as a segment (one dimension), a circle-like figure (two dimensions), or a multidimensional sphere (three and more dimensions). As a result, we used the variant of morphospace that reproduces the variations in skull size (SZM model), and another one that reproduces the variation in skull proportions and shape (SHM model) (Puzachenko, 2016). A dimensionality (d) of morphospace (= number of NMDS model axes) is estimated using Kruskal's stress (Kruskal, 1964; Kupriyanova et al., 2003). Coordinates of morphological spaces are used as generalized variables containing information on the size and shape variability of skull.

Allometric relationships act as a potential mechanism that narrows the SSD variability of male/female skulls. A principal component analysis (PCA) of the covariance matrix of log-transformed measurements was used for calculation of the multivariate allometric coefficient (MAC) (Jolicoeur, 1963; Klingenberg \& Froese, 1991; Klingenberg, 1996). According to Jolicoeur (1963), the coefficient (loading or eigenvalue) of a given measurement on a first principal component (PC1) divided by $1 / \sqrt{ } m$ (where $m$ is the number of measurements) is MAC. We calculated means of MACs using bootstrap method (1000 repeats). MAC values $>1.0$ indicate a positive allometry ("+"), MAC $\approx 1.0$ suggests an isometry ("1"), and MAC $<1.0$ is indicative of a negative allometry ("“-").

\section{Results}

The SZM model has a single dimension, which strongly correlates with most of the measurements and describes a "general size" of the Altai weasel skull. The dimensionality of SHM model was 4 (Table 2). The first axis of SHM model well correlated with the measurements. The result indicates a meaningful contribution of allometry to the variation of skull shape among males and females. The second axis (K2) correlated with a relative width of upper molar M1 (M1W) (Table 2), axis $\mathrm{K} 4$ - with relative mastiod width of skull (MW) and zygomatic width (ZyW). Axis K3 to the greatest extent correlated with the relative width of rostrum (RW) and minimal palatal width $(\mathrm{MpW})$. 
Table 1. Means and standard errors of $M$. altaica skull measurements, absolute mean difference between males and females $(\Delta \mathrm{S}, \mathrm{mm})$, ratio of $\Delta \mathrm{S}$ to average male size $(\Delta(\mathrm{M}-\mathrm{F}), \%)$, and SSD index $(\%)$.

\begin{tabular}{|c|c|c|c|c|c|}
\hline Measurements & Males & Females & $\Delta \mathrm{S}$ & $\Delta(\mathrm{M}-\mathrm{F})$ & SSD \\
\hline $\mathrm{CbL}$ & $48.9 \pm 0.13$ & $42.8 \pm 0.22$ & 6.1 & 12.5 & $6.7 \pm 0.29$ \\
\hline $\mathrm{NcL}$ & $31.1 \pm 0.10$ & $28.7 \pm 0.10$ & 2.4 & 7.6 & $4.0 \pm 0.24$ \\
\hline $\mathrm{VcL}$ & $23.1 \pm 0.11$ & $18.6 \pm 0.16$ & 4.5 & 19.5 & $10.8 \pm 0.46$ \\
\hline $\mathrm{MpW}$ & $4.4 \pm 0.02$ & $3.9 \pm 0.03$ & 0.6 & 12.5 & $6.7 \pm 0.46$ \\
\hline PL & $20.8 \pm 0.08$ & $17.9 \pm 0.16$ & 2.9 & 14.1 & $7.6 \pm 0.46$ \\
\hline MxtL & $13.6 \pm 0.04$ & $11.9 \pm 0.06$ & 1.7 & 12.2 & $6.5 \pm 0.29$ \\
\hline PM4L & $5.1 \pm 0.02$ & $4.5 \pm 0.03$ & 0.6 & 11.6 & $6.1 \pm 0.35$ \\
\hline $\mathrm{AbL}$ & $16.1 \pm 0.06$ & $14.3 \pm 0.07$ & 1.8 & 11.3 & $6.0 \pm 0.30$ \\
\hline $\mathrm{BcL}$ & $19.7 \pm 0.07$ & $17.3 \pm 0.09$ & 2.4 & 12.0 & $6.4 \pm 0.30$ \\
\hline ZyW & $25.1 \pm 0.09$ & $21.0 \pm 0.10$ & 4.1 & 16.5 & $9.0 \pm 0.30$ \\
\hline MW & $22.3 \pm 0.06$ & $19.3 \pm 0.08$ & 3.1 & 13.7 & $7.4 \pm 0.24$ \\
\hline PoW & $9.4 \pm 0.05$ & $8.5 \pm 0.05$ & 0.9 & 9.6 & $5.0 \pm 0.40$ \\
\hline IW & $9.9 \pm 0.04$ & $8.3 \pm 0.05$ & 1.6 & 16.4 & $8.9 \pm 0.36$ \\
\hline RW & $9.3 \pm 0.06$ & $7.8 \pm 0.08$ & 1.5 & 16.1 & $8.8 \pm 0.56$ \\
\hline $\mathrm{GpW}$ & $14.5 \pm 0.05$ & $12.5 \pm 0.07$ & 2.0 & 13.9 & $7.5 \pm 0.32$ \\
\hline $\mathrm{AbW}$ & $7.1 \pm 0.04$ & $6.1 \pm 0.05$ & 1.0 & 13.5 & $7.2 \pm 0.50$ \\
\hline M1W & $3.9 \pm 0.02$ & $3.4 \pm 0.03$ & 0.5 & 12.7 & $6.8 \pm 0.44$ \\
\hline $\mathrm{CH}$ & $18.6 \pm 0.06$ & $16.0 \pm 0.14$ & 2.6 & 14.0 & $7.5 \pm 0.44$ \\
\hline ML & $26.9 \pm 0.09$ & $22.8 \pm 0.13$ & 4.1 & 15.3 & $8.3 \pm 0.31$ \\
\hline $\mathrm{AL}$ & $24.7 \pm 0.08$ & $20.9 \pm 0.12$ & 3.8 & 15.5 & $8.4 \pm 0.30$ \\
\hline MatL & $16.2 \pm 0.05$ & $14.0 \pm 0.08$ & 2.2 & 13.6 & $7.3 \pm 0.30$ \\
\hline M1L & $5.7 \pm 0.02$ & $4.9 \pm 0.03$ & 0.8 & 13.8 & $7.4 \pm 0.36$ \\
\hline $\mathrm{MaH}$ & $12.8 \pm 0.06$ & $10.6 \pm 0.08$ & 2.1 & 16.8 & $9.2 \pm 0.43$ \\
\hline
\end{tabular}

SSD is the most important factor constraining size and shape variability of skull in Altai weasel adults, as follow from the scatterplot (Fig. 1). Along the axis E ("general size"), there was a gap between female and male samples. Along the axis K1 ("general shape") a gap was absent, but despite this, there were significant gender differences in cranial proportions.

Table 1 shows descriptive statistics. All craniological measurements had statistically significant differences, with the females being smaller than the males (Fig. 2). Average absolute differences in condylobasal length between sexes were more than $6 \mathrm{~mm}$, or $12.5 \%$, and the largest sex difference was found in the viscerocranium length (19.5\%).

A high SSD in cranial characters of $M$. altaica was accompanied by significant differences in allometric variation. Allometric profiles of both sexes based on means of MAC are shown in Fig. 3. Largest allometric differences were found in the width of auditory bulla $(\mathrm{AbW})$, the width of upper molar M1 (M1W), and cranial height $(\mathrm{CH})$.

Allometric patterns in some cranial characters were different between sexes. In the males, the width of auditory bulla had a high positive allometry, whereas in the

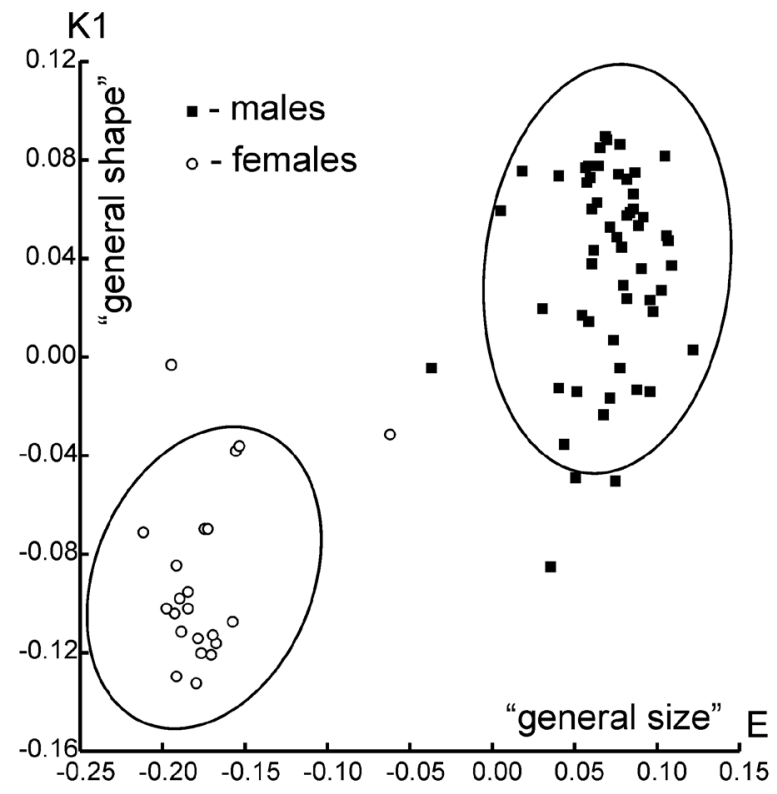

Fig. 1. Scatterplot of the dimension of SZM model (E) and first dimension of SHM model (K1) based on the NMDS analysis of Mustela altaica. 
Table 2. Spearman rank correlations for measurements and indexes (/CbL) of Altai weasel skulls with NMDS axes of SZM (E) and SHM (K1-K4) models of morphospace.

\begin{tabular}{|c|c|c|c|c|c|c|c|c|c|}
\hline \multirow{2}{*}{ Measurements } & \multicolumn{5}{|c|}{ Row measurements } & \multicolumn{4}{|c|}{ Indexes } \\
\hline & $\mathrm{E}$ & $\mathrm{K} 1$ & $\mathrm{~K} 2$ & $\mathrm{~K} 3$ & $\mathrm{~K} 4$ & K1 & $\mathrm{K} 2$ & $\mathrm{~K} 3$ & $\mathrm{~K} 4$ \\
\hline $\mathrm{CbL}$ & 0.97 & 0.63 & -0.16 & 0.00 & 0.02 & & & & \\
\hline $\mathrm{NcL}$ & 0.88 & 0.58 & -0.06 & -0.09 & 0.04 & -0.65 & 0.19 & -0.27 & 0.17 \\
\hline $\mathrm{VcL}$ & 0.86 & 0.65 & -0.21 & 0.16 & -0.08 & 0.62 & -0.17 & 0.27 & -0.24 \\
\hline $\mathrm{MpW}$ & 0.71 & 0.38 & -0.09 & 0.31 & -0.32 & -0.38 & 0.04 & 0.42 & -0.42 \\
\hline PL & 0.93 & 0.61 & -0.21 & 0.03 & -0.02 & 0.29 & -0.19 & 0.06 & -0.02 \\
\hline MxtL & 0.92 & 0.67 & -0.17 & 0.10 & 0.00 & -0.05 & 0.09 & 0.08 & -0.14 \\
\hline PM4L & 0.86 & 0.47 & -0.06 & 0.11 & -0.10 & -0.42 & 0.20 & 0.21 & -0.11 \\
\hline $\mathrm{AbL}$ & 0.94 & 0.65 & -0.17 & -0.03 & 0.03 & -0.29 & -0.12 & -0.16 & 0.13 \\
\hline $\mathrm{BcL}$ & 0.92 & 0.69 & -0.13 & -0.04 & 0.06 & 0.00 & 0.03 & -0.21 & 0.22 \\
\hline $\mathrm{ZyW}$ & 0.92 & 0.70 & -0.19 & -0.09 & -0.26 & 0.61 & -0.07 & -0.08 & -0.61 \\
\hline MW & 0.91 & 0.59 & -0.14 & -0.05 & -0.28 & 0.16 & 0.13 & -0.11 & -0.82 \\
\hline PoW & 0.77 & 0.41 & 0.14 & -0.06 & -0.35 & -0.57 & 0.35 & -0.30 & -0.41 \\
\hline IW & 0.87 & 0.54 & -0.31 & 0.03 & -0.26 & 0.33 & -0.30 & 0.06 & -0.51 \\
\hline RW & 0.78 & 0.41 & -0.16 & 0.35 & -0.27 & -0.01 & -0.08 & 0.48 & -0.39 \\
\hline GpW & 0.85 & 0.68 & 0.08 & -0.02 & -0.19 & 0.31 & 0.44 & -0.09 & -0.53 \\
\hline $\mathrm{AbW}$ & 0.80 & 0.46 & -0.19 & -0.09 & -0.31 & -0.13 & -0.12 & -0.31 & -0.53 \\
\hline $\mathrm{M} 1 \mathrm{~W}$ & 0.77 & 0.56 & 0.35 & 0.15 & -0.11 & -0.03 & 0.78 & 0.16 & -0.16 \\
\hline $\mathrm{CH}$ & 0.86 & 0.58 & 0.11 & -0.14 & -0.23 & 0.15 & 0.50 & -0.27 & -0.50 \\
\hline $\mathrm{ML}$ & 0.94 & 0.69 & -0.27 & 0.03 & -0.07 & 0.69 & -0.27 & 0.14 & -0.34 \\
\hline $\mathrm{AL}$ & 0.95 & 0.67 & -0.28 & -0.01 & -0.10 & 0.70 & -0.26 & 0.11 & -0.36 \\
\hline MatL & 0.91 & 0.69 & -0.18 & 0.06 & 0.04 & 0.46 & 0.14 & 0.12 & -0.18 \\
\hline M1L & 0.79 & 0.71 & 0.05 & 0.22 & 0.01 & 0.38 & 0.39 & 0.37 & -0.13 \\
\hline $\mathrm{MaH}$ & 0.81 & 0.60 & -0.18 & -0.01 & -0.16 & 0.47 & -0.05 & -0.01 & -0.33 \\
\hline
\end{tabular}
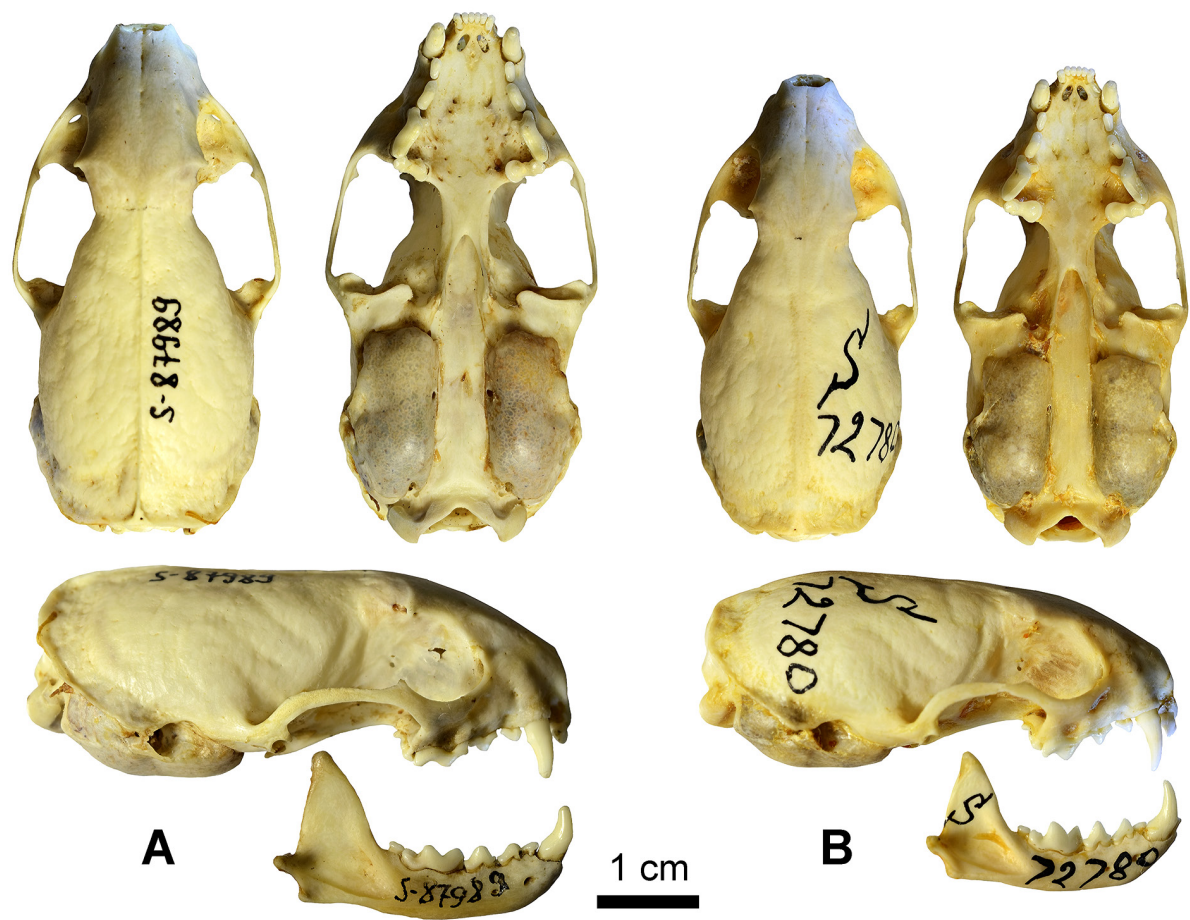

Fig. 2. Skulls of the Altai weasel Mustela altaica from the delta of Ili River, Kazakhstan. A — male ZMMU S-87989, B — female ZMMU S-72780. 
Table 3. Multivariate allometric coefficient (MAC) of males and females of Altai weasels.

\begin{tabular}{|c|c|c|c|c|c|c|}
\hline \multirow[b]{2}{*}{ Measurements } & \multicolumn{3}{|c|}{ Males } & \multicolumn{3}{|c|}{ Females } \\
\hline & MAC & $\begin{array}{c}\text { lower - upper } \\
\text { quartile }\end{array}$ & $\begin{array}{l}\text { sign of } \\
\text { allometry }\end{array}$ & MAC & $\begin{array}{l}\text { lower - upper } \\
\text { quartile }\end{array}$ & $\begin{array}{c}\text { sign of } \\
\text { allometry }\end{array}$ \\
\hline $\mathrm{CbL}$ & 0.91 & $0.87-0.95$ & “__“ & 0.95 & $0.87-1.02$ & "1" \\
\hline $\mathrm{NcL}$ & 0.62 & $0.51-0.71$ & “__“ & 0.45 & $0.38-0.50$ & “"_" \\
\hline $\mathrm{VcL}$ & 1.28 & $1.14-1.44$ & " $+"$ & 1.51 & $1.40-1.60$ & " + " \\
\hline $\mathrm{MpW}$ & 0.75 & $0.59-0.94$ & “__“ & 1.08 & $0.95-1.21$ & $" 1 "$ \\
\hline PL & 1.19 & $1.13-1.25$ & " $+"$ & 1.56 & $1.40-1.69$ & " $+"$ \\
\hline MxtL & 0.79 & $0.72-0.86$ & “"_" & 0.97 & $0.92-1.02$ & $" 1 "$ \\
\hline PM4L & 0.79 & $0.73-0.87$ & “‘_“ & 1.00 & $0.93-1.07$ & "1" \\
\hline $\mathrm{AbL}$ & 1.07 & $0.99-1.15$ & "1" & 0.75 & $0.72-0.82$ & “__“" \\
\hline $\mathrm{BcL}$ & 1.02 & $0.92-1.13$ & "1" & 0.77 & $0.67-0.83$ & “__“ \\
\hline $\mathrm{ZyW}$ & 1.08 & $1.02-1.13$ & $\approx " 1 "$ & 0.78 & $0.72-0.86$ & “__" \\
\hline MW & 0.89 & $0.86-0.93$ & ““_“ & 0.64 & $0.59-0.70$ & “__“ \\
\hline PoW & 0.87 & $0.74-1.02$ & “_”“ & 0.40 & $0.28-0.52$ & “__“ \\
\hline IW & 1.25 & $1.17-1.33$ & " $+"$ & 0.60 & $0.51-0.68$ & ““_” \\
\hline RW & 1.39 & $1.13-1.64$ & " +" & 0.98 & $0.76-1.23$ & "1" \\
\hline GpW & 0.79 & $0.71-0.88$ & “__“ & 0.82 & $0.72-0.95$ & “__“ \\
\hline $\mathrm{AbW}$ & 1.48 & $1.32-1.66$ & " $+"$ & 0.24 & $0.10-0.41$ & “_-” \\
\hline M1W & 0.52 & $0.36-0.66$ & ““_” & 1.26 & $1.13-1.41$ & "++" \\
\hline $\mathrm{CH}$ & 0.75 & $0.63-0.85$ & ““_” & 1.16 & $1.02-1.35$ & "“+" \\
\hline ML & 1.05 & $0.98-1.12$ & "1" & 1.08 & $1.02-1.13$ & $\approx " 1 "$ \\
\hline $\mathrm{AL}$ & 0.99 & $0.94-1.04$ & "1" & 1.07 & $1.03-1.11$ & $\approx " 1 "$ \\
\hline MatL & 0.77 & $0.71-0.83$ & ““_" & 1.08 & $1.04-1.13$ & $\approx " 1 "$ \\
\hline M1L & 0.51 & $0.41-0.62$ & ““_” & 0.92 & $0.81-1.06$ & $\approx " 1 "$ \\
\hline $\mathrm{MaH}$ & 1.12 & $0.98-1.24$ & "++" & 1.30 & $1.22-1.41$ & "++" \\
\hline
\end{tabular}

females such allometry was very weak (Table 3 ). The width of upper molar M1 and cranial height showed a high negative allometry in the males versus a high positive allometry in the females (Fig. 4A). The interorbital width (IW) had a positive allometry in the males and a negative allometry in the females (Fig. 4B).

\section{Discussion}

A high degree of the sexual dimorphism has been found in the Altai weasel, with the males being larger than the females by all the characters studied. An average SSD (ASSD) in the population studied is 7.4 (Table 4). Compared to hitherto studies of the cranial variation in Mustela species based on the same set of characters (Abramov \& Puzachenko, 2009; Abramov et al., 2016), a high degree of SSD was found for all the species studied (Fig. 5). ASSD of $M$. altaica lies within the genus Mustela range, and it is close to that of $M$. erminea population from Baraba Steppe in West Siberia (Abramov \& Puzachenko, 2012). An intraspecific variation of ASSD in the Mustela species could be indirect

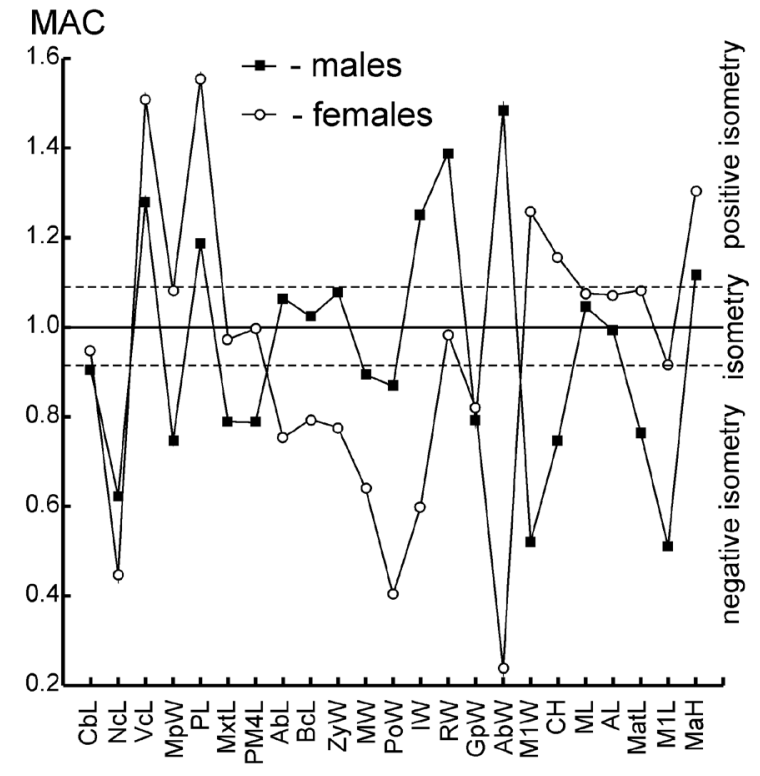

Fig. 3. Allometric profiles of males and females of Mustela altaica (MAC - multivariate allometric coefficients). 

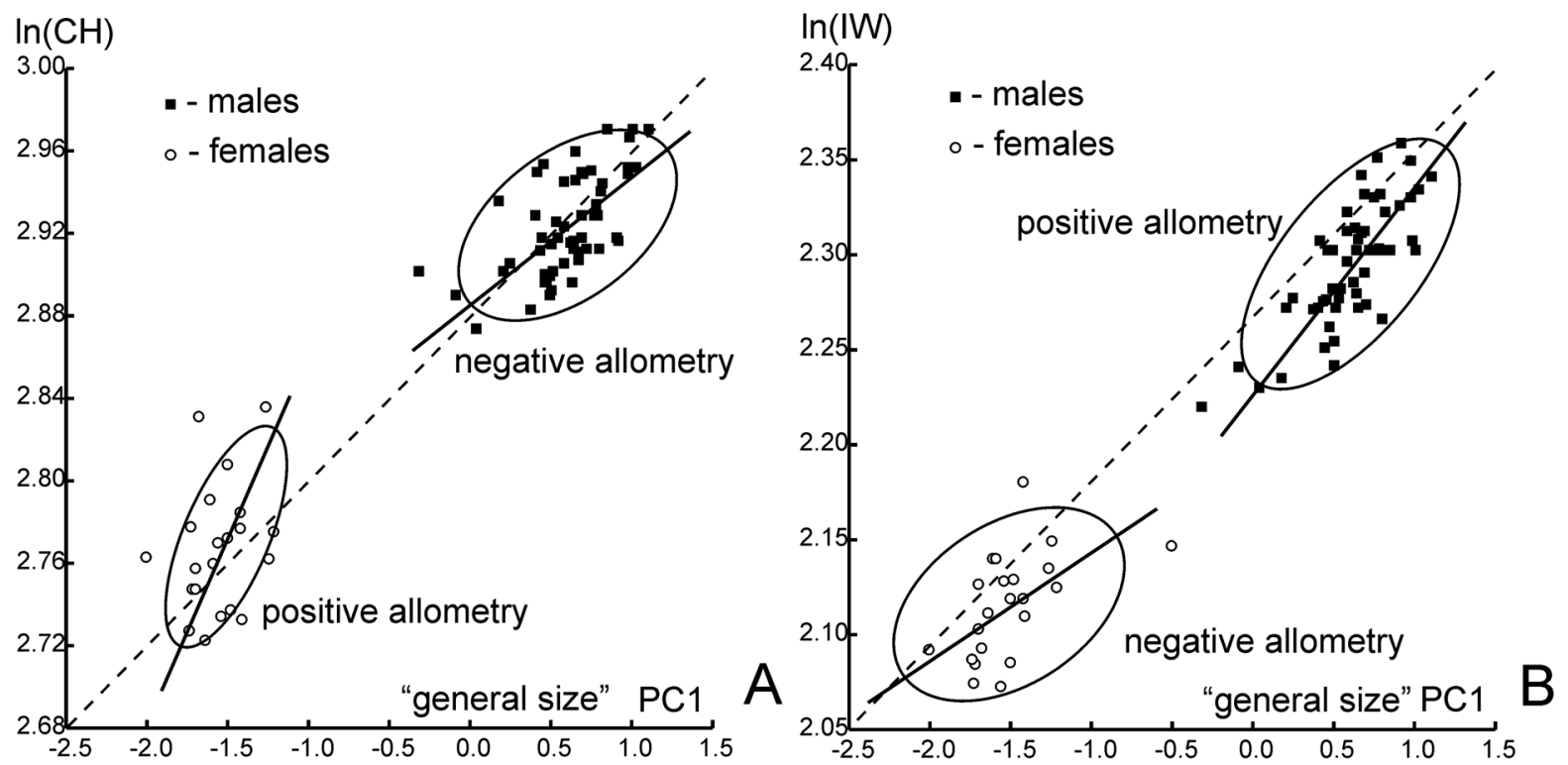

Fig. 4. Allometric patterns of log-transformed cranial characters of Mustela altaica. A - cranial height (CH), B - interorbital width (IW); PC1 - first principal component; dotted line indicates isometry.

Table 4. Average sexual size dimorphism (ASSD) of mustelid skulls.

\begin{tabular}{|c|c|c|}
\hline Species & ASSD & Comments \\
\hline Mustela altaica & 7.4 & this study \\
\hline Mustela putorius & $6.7^{1} ; 6.9^{2} ; 8.4$ & $\begin{array}{l}{ }^{1} 15 \text { variables, data from De Marinis (1995); }{ }^{2} 15 \text { variables, data from } \\
\text { Smetanová (2011); Abramov \& Puzachenko (2009); Abramov et al. } \\
\text { (2016) }\end{array}$ \\
\hline Mustela eversmanii & 5.1 & $\begin{array}{l}25 \text { variables, data from Abramov \& Puzachenko (2009); Abramov } \\
\text { et al. (2016) }\end{array}$ \\
\hline Mustela sibirica & $5.9 ; 6.6 ; 9.3$ & $\begin{array}{l}25 \text { variables, data from Abramov \& Puzachenko (2009), Abramov } \\
\text { et al. (2016) }\end{array}$ \\
\hline Mustela erminea & $6.7^{3} ; 7.3$ & ${ }^{3} 30$ variables, data from Yurgenson (1933) \\
\hline Mustela nivalis & 11.0 & 13 variables, data from Schmidt (1992) \\
\hline Mustela lutreola & 5.1 & Abramov \& Puzachenko (2009); Abramov et al. (2016) \\
\hline Vormela peregusna & $2.5-3.9$ & Puzachenko et al. (2017) \\
\hline Neovison vison & $2.5^{4} ; 6.9^{5}$ & $\begin{array}{l}{ }^{4} 21 \text { variables, farm American mink, data from Jakubowski et al. } \\
\qquad \begin{array}{l}(2008) ; \\
{ }^{5} 16 \text { variables, feral American mink, data from Wiig (1982) }\end{array}\end{array}$ \\
\hline Lutra lutra & $2.8-4.6$ & 22 variables, data from Baryshnikov \& Puzachenko (2012). \\
\hline Martes martes & 4.5 & $\begin{array}{l}14 \text { variables, data from Rossolimo \& Pavlinov (1974); Pavlinov } \\
\text { (1977) }\end{array}$ \\
\hline Meles meles & $1.2-1.8$ & $\begin{array}{l}30 \text { variables, data from Baryshnikov et al. (2003); Abramov } \\
\& \text { Puzachenko (2005, 2006, 2007); Abramov et al. (2009) }\end{array}$ \\
\hline Meles leucurus & $1.8-2.9$ & $\begin{array}{l}30 \text { variables, data from Baryshnikov et al. (2003); Abramov } \\
\& \text { Puzachenko (2005, 2006, 2007); Abramov et al. (2009) }\end{array}$ \\
\hline Meles canescens & 2.7 & $\begin{array}{l}30 \text { variables, data from Baryshnikov et al. (2003); Abramov } \\
\& \text { Puzachenko (2005, 2006, 2007); Abramov et al. (2009) }\end{array}$ \\
\hline
\end{tabular}




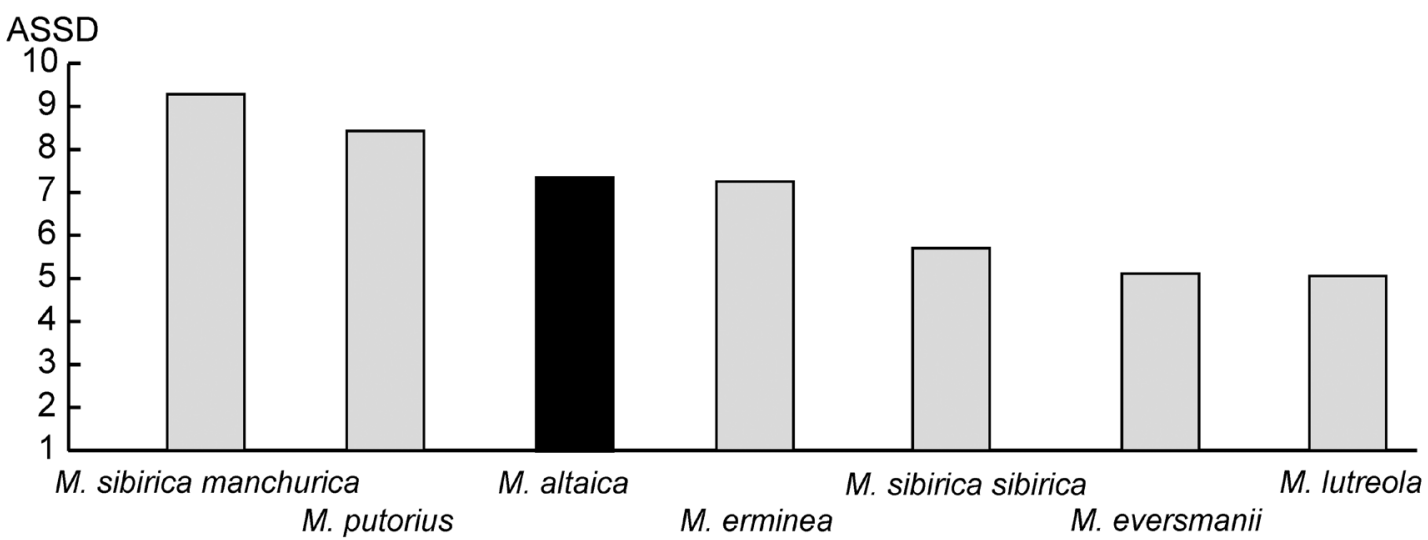

Fig. 5. Average SSD (ASSD) in different Mustela species.

evidence for sensitivity of the mechanisms regulating the skull growth to environmental factors.

SSD in the mustelids varies from a relatively low one in badgers (Meles spp.) and the river otter Lutra lutra to a high SSD in some of Mustela species (Table 4). A high variation of the average SSD in the mustelids could depend on a different set of characters, a geographic variability or species-specific patterns (see also Abramov \& Puzachenko, 2009). Noonan et al. (2016) stressed upon the fundamental role of diet in SSD level in Musteloidea. SSD is highest among those musteloid species having the diet dominated by high energy, less abundant items (e.g., small vertebrate prey), and is lower where low energy, abundant items dominate the diet (e.g., for insectivory and mixed omnivory). A high degree of SSD in all Mustela species, including M. altaica, is in good concordance with their carnivorous diet.

Allometric comparisons are important in clarifying cranial shape differences that depend on a size (Klingenberg, 1996). A difference in allometric patterns between sexes of the Altai weasel was found for the size and shape of cranial characters. Sexual differences in allometric patterns suggest that the females are not merely a smallsized variant of the males. The SSD of the Altai weasel is a result of differences in the scale and allometry of cranial characters between sexes. Therefore, it should reflect features of male-female allometric ontogenetic patterns.

Three main hypotheses were proposed to explain the male-biased SSD in Mustelidae and other Carnivora (Holmes \& Powell, 1994; King \& Powell, 2007): 1) resource partition that allows reducing food competition between sexes; 2) sexual selection, where males compete for access to mates, or females; 3 ) bioenergetics, which includes the differences in reproductive strategies between sexes. None of existing research provides convincing evidence in favour of a single hypothesis. Further studies of a geographical variation in sexual dimorphism of the Altai weasel, a comparative analysis of its SSD and sympatrically distributed other Mustela species (i.e., $M$. eversmanii or M. erminea), and additional studies of their feeding and intraspecific behaviour could be instrumental in clarifying reasons for the SSD phenomenon.
ACKNOWLEDGEMENTS. We are thankful to Vladimir Lebedev, Sergei Kruskop, and Sergei Pole for access to the collections used in this work. We are obliged to Dmitry V. Logunov (Manchester Museum) for improving the English of the final draft. We thank to two anonymous reviewers for the constructive comments on the earlier draft of this manuscript. The study was supported in part by the Russian Foundation for Basic Research (grant 19-54-50001), Joint Research Project Grant from the Japan Society for the Promotion of Science (JSPS) and the programs of the Ministry of Science and Higher Education of the Russian Federation (0148-2019-0007, AAAA-A19-119021990093-8 and AAAA-A19-119032590102-7).

\section{References}

Abramov A.V. 2016. Mustela altaica. The IUCN Red List of Threatened Species 2016: e.T41653A45213647. http://dx.doi.org/10.2305/IUCN.UK.2016-1.RLTS. T41653A45213647.en. Downloaded on 15 March 2019.

Abramov A.V. \& Puzachenko A.Yu. 2005. Sexual dimorphism of craniological characters in Eurasian badgers, Meles spp. (Carnivora, Mustelidae) // Zoologischer Anzeiger. Vol.244. P.11-29.

Abramov A.V. \& Puzachenko A.Yu. 2006. Geographical variability of skull and taxonomy of Eurasian badgers (Mustelidae, Meles) // Zoologicheskii Zhurnal. Vol.85. P.641-655.

Abramov A.V. \& Puzachenko A.Yu. 2007. [Possible hybridization between Meles meles and M. leucurus (Carnivora, Mustelidae) in Western Tien Shan] // Rozhnov V.V. \& Tembotova F.A. (eds.). [Mammals of Mountain Territories]. Moscow: KMK Scientific Press. P.4-7 [in Russian].

Abramov A.V. \& Puzachenko A.Yu. 2009. Spatial variation of sexual dimorphism in the Siberian weasel Mustela sibirica (Mustelidae, Carnivora) // Russian Journal of Theriology. Vol.8. P.17-28.

Abramov A.V. \& Puzachenko A.Yu. 2012. Species co-existence and morphological divergence in West Siberian mustelids (Carnivora, Mustelidae) // Mammal Study. Vol.37. P.255-259.

Abramov A.V., Puzachenko A.Yu. \& Wiig Ø. 2009. Cranial variation in the European badger Meles meles (Carnivora, 
Mustelidae) in Scandinavia // Zoological Journal of the Linnean Society. Vol.157. P.433-450.

Abramov A.V., Puzachenko A.Yu. \& Masuda R. 2018. Cranial variation in the Siberian weasel Mustela sibirica (Carnivora, Mustelidae) and its possible taxonomic implications // Zoological Studies. 57: 14.

Abramov A.V. \& Tumanov I.L. 2003. Sexual dimorphism in the skull of the European mink Mustela lutreola (Carnivora, Mustelidae) from NW part of Russia // Acta Theriologica. Vol.48. No. 2. P.239-246.

Abramov A.V., Puzachenko A.Yu. \& Tumanov I.L. 2016. Morphological differentiation of the skull in two closely-related mustelid species (Carnivora: Mustelidae) // Zoological Studies. 55: 1.

Abramov A.V., Puzachenko A.Yu. \& Wiig Ø. 2009. Cranial variation in the European badger Meles meles (Carnivora, Mustelidae) in Scandinavia // Zoological Journal of Linnean Society. Vol.157. P.433-450.

Baryshnikov G.F. \& Puzachenko A.Yu. 2011. Craniometrical variability of cave bears (Carnivora, Ursidae): Multivariate comparative analysis // Quaternary International. Vol.245. P.350-368.

Baryshnikov G.F. \& Puzachenko A.Yu. 2012. Craniometrical variability of the Eurasian otter (Lutra lutra: Carnivora: Mustelidae) from the Northern Eurasia // Proceedings of the Zoological Institute of the Russian Academy of Sciences. Vol.316. P.203-222.

Baryshnikov G.F. \& Puzachenko A.Yu. 2017. Morphometric analysis of metacarpal and metatarsal bones of cave bears (Carnivora, Ursidae) // Fossil Imprint. Vol.73. P.7-47.

Baryshnikov G.F., Puzachenko A.Yu. \& Abramov A.V. 2003. New analysis of variability of check teeth in Eurasian badgers (Carnivora, Mustelidae, Meles) // Russian Journal of Theriology. Vol.1. P.133-149.

Davison M.L. \& Jones L.E. 1983. Special issue: multidimensional scaling and its applications // Applied Psychological Measurement. Vol.7. P.373-514.

De Marinis A.M. 1995. Craniometric variability of polecat Mustela putorius L. 1758 from North-Central Italy // Hystrix (n.s.). Vol.7. P.57-68.

Heptner V.G., Naumov N.P., Yurgenson P.B., Sludsky A.A., Chirkova A.F. \& Bannikov A.G. 1967. [Mammals of the Soviet Union. Vol.2, pt. 1. Sea Cows and Carnivora]. Moscow: Vysshaya Shkola. 1000 p. [in Russian].

Holmes T. \& Powell R.A. 1994. Morphology, ecology, and the evolution of sexual dimorphism in North American Martes // Buskirk S.W., Harestad A.S., Raphael M.G. \& Powell R.A. (eds.). Martens, Sables, and Fishers: Biology and Conservation. Ithaca \& London: Cornell University Press. P.72-84.

Jakubowski H., Komosa M. \& Frąckowiak H. 2008. Allometric analysis of cranial parameters of American mink, including bones of masticatory apparatus // Electronic Journal of Polish Agricultural Universities. Vol.11. No.3. http://www. ejpau.media.pl/volume11/issue3/art-02.html. Accessed 20 November 2014.

Jolicoeur P. 1963. Note: The multivariate generalization of the allometry equation // Biometrics. Vol.9. P.497-499.

Kendall M.G. 1975. Rank Correlation Methods. London: Charles Griffin and Co. 202 p.

King C.M. \& Powell R.A. 2007. The natural history of weasels and stoats: ecology, behavior, and management. New York: Oxford University Press. 446 p.
Klingenberg C.P. 1996. Multivariate allometry // Marcus L.F., Corti M., Loy A., Naylor G.J.P. \& Slice D.E. (eds.). Advances in Morphometrics. New York: Plenum Press. P.23-49.

Klingenberg C.P. \& Froese R. 1991. A multivariate comparison of allometric growth patterns // Systematic Zoology. Vol.40. P.410-419.

Kruskal B. 1964. Multidimensional scaling by optimizing goodness of fit to nonmetric hypothesis // Psychometrika. Vol.29. P.1-27.

Kupriyanova I.F., Puzachenko A.Yu. \& Agadzhanyan A.K. 2003. Spatial and temporal variation of cranial parameters in the common shrew, Sorex araneus (Insectivora) // Zoologicheskii Zhurnal. Vol.82. P. 839-851 [in Russian with English summary].

Pavlinov I.Ya. 1977. Age variation of the skull in the pine-marten (Martes martes L.: Mammalia, Mustelidae) // Byulleten' Moskovskogo Obshchestva Estestvoispytatelei. Vol.82. P.33-50 [in Russian].

Puzachenko A.Yu. 2001. Skull variability in the common mole rat Spalax microphthalmus (Spalacidae, Rodentia). 1. A method for analysis of data, non-age variability in males // Zoologicheskii Zhurnal. Vol.80. P. 343-357 [in Russian with English summary].

Puzachenko A.Yu. 2016. The quantitative patterns of morphological disparity of mammalian skull // Archive of Zoological Museum of Lomonosov Moscow State University. Vol.54. P.229-268 [in Russian with English summary].

Puzachenko A.Yu., Abramov A.V. \& Rozhnov V.V. 2017. Cranial variation and taxonomic content of the marbled polecat Vormela peregusna (Mustelidae, Carnivora) // Mammalian Biology. Vol.83. P.10-20.

Ralls K. \& Harvey P. H. 1985. Geographic variation in size and sexual dimorphism of North American weasels //Biological Journal of the Linnean Society. Vol.25. P.119-167.

Reichstein H. 1957. Schädelvariabilität europäischer Mauswiesel (Mustela nivalis L.) und Hermeline (Mustela erminea L.) in Beziehung zu Verbreitung und Geschlecht // Zeitschrift für Säugetierkunde. T.22. S.151-182.

Reig S. 1997. Biogeographic and evolutionary implications of size variation in North American least weasel (Mustela nivalis)//Canadian Journal of Zoology. Vol.75. P.2036-2049.

Rossolimo O.L. \& Pavlinov I.Ya. 1974. Sexual dimorphism in the development, size and proportions of the skull in the pine marten (Martes martes L.: Mammalia, Mustelidae). Byulleten'Moskovskogo Obshchestva Estestvoispytatelei. Vol.79. P.23-35 [in Russian with English summary].

Schmidt K. 1992. Skull variability of Mustela nivalis Linnaeus, 1766 in Poland // Acta Theriologica. Vol.37. P.141-162.

Sludsky A.A., Afanasiev Y.G., Bekenov A., Grachev Y.A., Lobachev Y.S., Makhmutov S., Strautman E.I., Fedoseenko A.K. \& Shubin I.G. 1982. [Mammals of Kazakhstan. Vol. 3, pt 2. Carnivora (Mustelidae, Felidae)]. Alma-Ata: Nauka. 263 p. [in Russian].

Smetanová Z. 2011. Craniometric characteristics of the European polecat populations in the Czech Republic. MS Dissertation. Brno: Masaryk University.

Wiig Ø. 1982. Sexual dimorphism in the skull of the feral American mink (Mustela vison Schreber) // Zoologica Scripta. Vol.11. P.315-316.

Yurgenson P.B. 1933. Skull variation in the ermine (Mustela erminea L.) // Zoologicheskii Zhurnal. Vol.11. P.60-68. 